\title{
Operator of Medical Device
}

National Cancer Institute

\section{Source}

National Cancer Institute. Operator of Medical Device. NCI Thesaurus. Code C53272.

An individual who handles and controls the functioning of medical device. 